\title{
Characterization of Solar Cells Based Natural Chlorophyll and P3HT Polymer
}

\author{
Agus Supriyanto $^{1}$, Fahru Nurosyid ${ }^{1}$, Yofentina Iriani ${ }^{1}$, Kuwat Triyana ${ }^{2}$, Ari H Remalan ${ }^{1}$ \\ ${ }^{1}$ Physics Department, Faculty of Mathematics and Sciences, SebelasMaret University, \\ Surakarta, Indonesia \\ ${ }^{2}$ Physics Department, Faculty of Mathematics and Sciences, GadjahMada University, \\ Yogyakarta, Indonesia
}

\begin{abstract}
Characterization of organic solar cells based organic material and polymer using natural chlorophyll and P3HT have been investigated using current-voltage $(I-V)$ Keithley 2602 instrument. Chlorophyll is extracted from Spirulina sp by column chromatography method. It is found that the absorbance spectra of chlorophyll is at $410 \mathrm{~nm}$ and $667 \mathrm{~nm}$ while 450-650 $\mathrm{nm}$ for P3HT polymer. The electrical properties of chlorophyll and P3HT show a linear increase of current in response to light. The I-V characteristics of the organic solar cells is measured by using xenon light at intensity of $100 \mathrm{mWatt} / \mathrm{cm}^{2}$ and area of $10 \mathrm{~mm}^{2}$. It is obtained that the organic solar cells having 7 layers of P3HT has the best $I-V$ characteristics, short circuit current $I_{s c} 2,69 \times 10^{-2} \mathrm{~mA}$ and open circuit $V_{o c} 250 \mathrm{mV}$.
\end{abstract}

Keyword :organic solar cell, P3HT, chlorophyll, I-V characteristics.

\section{Introduction}

The use of conjugated polymers in solar cells have been carried out with a variety of theoretical studies, the synthesis of new materials and the search is done to improve the power conversion efficiency and the performance is so much better. One of the polymers are widely studied as the active ingredient is Poly 3hexylthiophene (P3HT) solar cells. P3HT is a material that is widely studied as an active ingredient of polymer solar cells. P3HT has the structure of regio-regular (RR) which is capable of producing high electrical conductivity, easily soluble in ordinary organic solvents ${ }^{1,2}$. The growth of P3HT film can be made in the form of films thin with simple techniques, such as spin-coating, dip-coating, inkjet printing and roll-to-roll printing. Otherwise the poli 3-hexylthiophene has a high charge carrier mobility ${ }^{3}$.

The technology development of sensitization from organic natural products has been attracting many researchers to study since there are available in the nature in a number of variety and large amounts. In the recent years, some researchers had developed the use of organic natural products including chlorophyll for various applications such as sensors, catalysts, solar cells, and optoelectronics ${ }^{4,5}$. Dye-sensitizing molecule from chlorophyll is one of those promising compounds to be used in optoelectronics devices. The advantage of this molecule is that with its low molecular weight yet gives high molar extinction and wide visible spectra ${ }^{6}$. The absorption spectra can be tuned to various wavelengths upon complex is formed using different captions for example magnesium, iron, zinc, silver, and copper.

Organic material of natural chlorophyll of Spirulina sp has complied characteristics as the active ingredient in solar cells ${ }^{7}$. Requirements for such materials as the active ingredient, namely solar cell material must be capable of being a medium of transfer electric charge carriers as a result of the absorbed photons ${ }^{8}$.

As one of the requirements of the dye that can function as sensitizing agent, the compound itself must be able to transfer electrical charge after absorbing the photon form visible lights ${ }^{9}$. In this work, chlorophyllporphyrin was isolated from spinach leaves and spirulina microalgae, a certain species of micro algae, and separated using column chromatography. The visible spectra were recorded mainly in the range of 400-700 $\mathrm{nm}$. The charge transfer process in the solution of chlorophyll-porphyrin was measured with or without radiation of visible lights to obtain photoconductive properties. The optoelectronics devices based on 
organic compounds are expected to be developed using chlorophyll. We observed that the visible spectra of chlorophyll are reminiscent of synthetic chlorophyll that have been long to be studied for solar cells. Upon radiation using visible lights, photoconductivity of chlorophyll isolated from spinach and spirulina micro algae are $6.0 \times 10^{-5} \mathrm{ohm}^{-1} \mathrm{~cm}^{-1}$ and $1.2 \times 10^{-4} \mathrm{ohm}^{-1} . \mathrm{cm}^{-1}$, respectively ${ }^{10}$.

\section{Methodology}

The P3HT polymers layer was deposited onto ITO substrate by spin coating technique using porphyrin solution in acetone. Then, chlorophyll was coated onto the film (ITO/ chlorophyll) by the same technique. The films were characterized by ultraviolet-visible (UV-Vis) spectrophotometer to investigate the optical absorption within a wavelength region from $300 \mathrm{~nm}$ to $800 \mathrm{~nm}$. Alumina electrode was prepared on the films by electron beam evaporation technique.

The current-voltage characteristics in dark at room temperature was obtained using a 2602A Keithley instrument. The performance under dark and illumination was performed to study the $I-V$ characteristic solar cells. The device was illuminated by a visible light from tungsten light source with adjusting the light intensity $100 \mathrm{mWcm}^{-2}$ was obtained. The intensity was controlled by solar power meter and temperature was measured by thermocouple. The illuminated cell area was $10 \mathrm{~mm}^{2}$. The photosensitizer parameters such as short circuit current density $\left(J_{s c}\right)$, and open circuit voltage $\left(V_{o c}\right)$ were obtained from the intersection axis of current and voltage from the currentvoltage curve under dark and illumination, respectively. Fig. 1 shows the structure of an organic solar cells of ITO/Pedot:PSS/P3HT/Chlorophyll/Al.

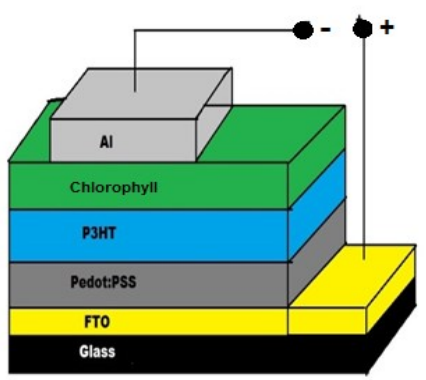

Fig.1. The structure of Solar Cells Organics of FTO/Pedot:PSS/P3HT/Chlorophyll/Al

\section{Results and Discussions}

\subsection{1 UV-vis Spectra of P3HT and Chlorophyll}

Fig. 2 shows the absorption spectra of P3HT film with $0.1 \%, 0.5 \%$ and $1 \%$ concentration. These spectra suggest that the P3HT films had been grown successfully on ITO substrate. The P3HT film shows the highest absorption under irradiation of UV and Visible with the wavelength range 400 to $650 \mathrm{~nm}$. Concentration increases, the absorbance will also increase. Fig. 3 shows the absorption spectra of chlorophyll film. The chlorophyll film by chromatography methods shows the highest absorption under irradiation of light with the peak of wavelength range 420 and $660 \mathrm{~nm}$.

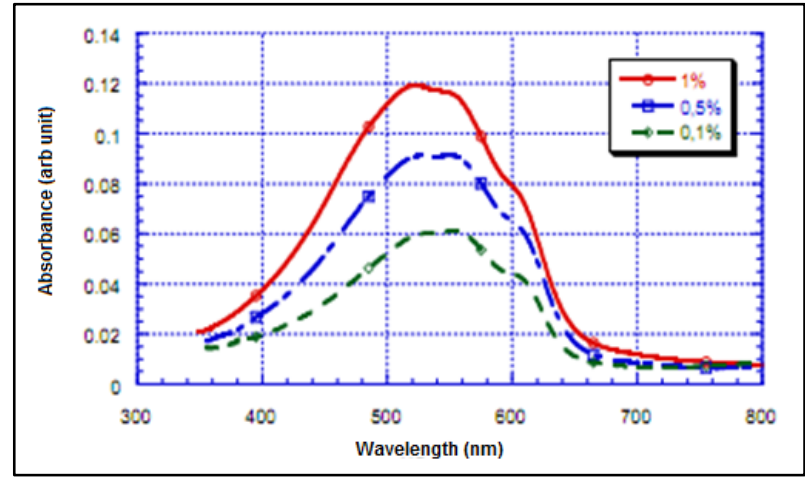

Fig. 2. Absorption spectra of P3HT film with $0.1 \%, 0.5 \%$ and $1 \%$ con

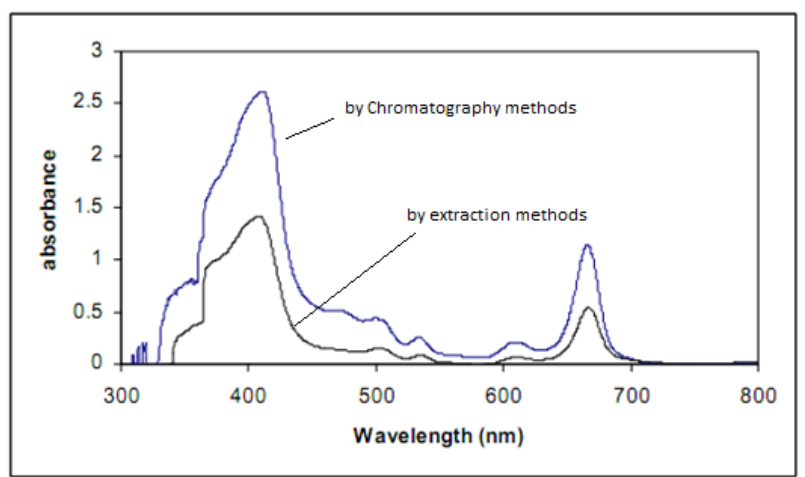

Fig.3.UV-Vis spectra of chlorophyll isolated from Indonesian spirulina microalgae by extraction and chromatography methods 


\subsection{Photoconductivity of P3HT}

The current-voltage behavior of a device prepared using natural $\mathrm{P} 3 \mathrm{HT}$ under dark and under illumination was then studied photoconductivity properties. A Keithley high voltage source Model 2606A and a personal computer were used in this experiment. The devices show photosensitizing effect, Figure. 4.

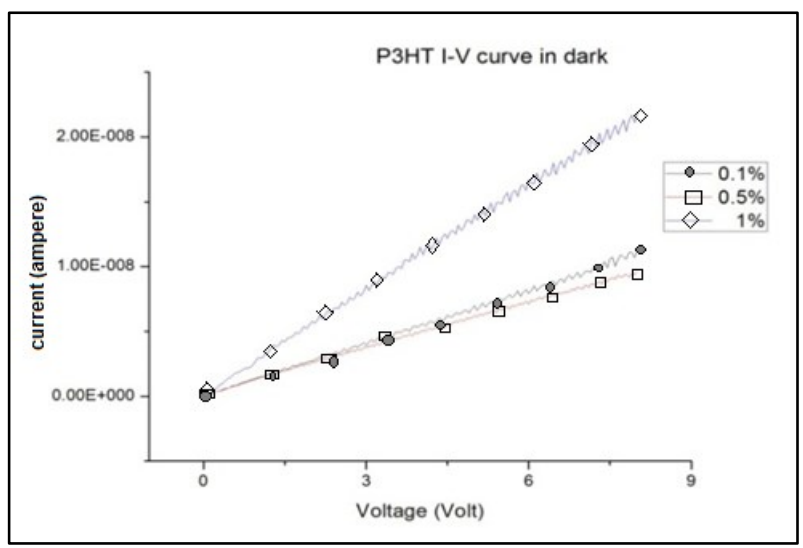

(a)

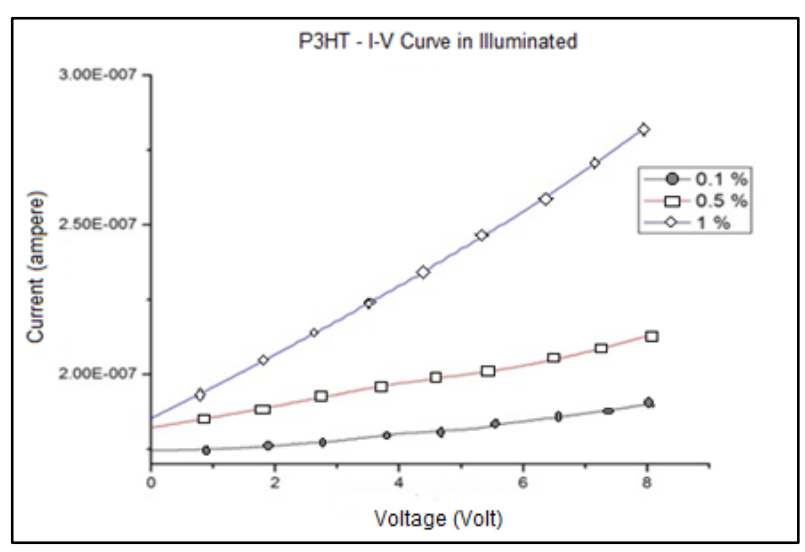

(b)

Fig. 4. The Current-Voltage Characteristics of P3HT films under dark (a) and illuminated conditions (b)

\subsection{3 The I-V Characteristics Solar Cells}

The $I-V$ characteristics of the organic solar cells was measured by using xenon light at intensity of 100 $\mathrm{mWatt} / \mathrm{cm}^{2}$ and area of $10 \mathrm{~mm}^{2}$. It was obtained that the organic solar cells having 7 layers of P3HT has the best $I-V$ characteristics, short circuit current $I_{s c}$
$2.69 \times 10^{-2} \mathrm{~mA}$, open circuit $V_{o c} 250 \mathrm{mV}$, fill factor $\mathrm{FF}$ $0.29 \%$ and efficiency $\eta 1.95 \times 10^{-2}$. Shown in Fig.5 is the $I-V$ characteristic of solar cells organics.

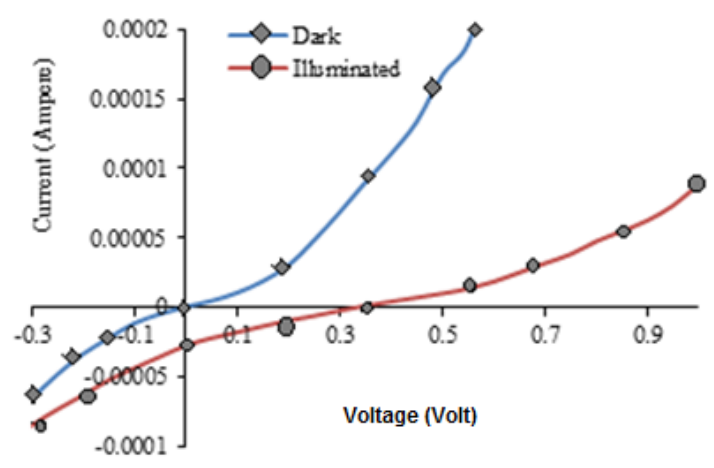

Fig. 6 . The $I-V$ characteristic of solar cells organics.

\section{Conclusions}

Poly 3-hexylthiophene (P3HT) film have been deposit by spin coating method. We have investigated the optical (absorption spectrum) and electrical (photoconductivity) characteristic of P3HT film. The absorption band of P3HT covers 400-650 nm. Absorbance of P3HT increases linearly with the concentration. The I-V characteristics of the organic solar cells was measured by using xenon light at intensity of $100 \mathrm{mWatt} / \mathrm{cm}^{2}$ and area of $10 \mathrm{~mm}^{2}$. It was obtained that the organic solar cells having 7 layers of P3HT has the best I-V characteristics, short circuit current $I_{s c} 2,69 \times 10^{-2} \mathrm{~mA}$ and open circuit $V_{o c} 250 \mathrm{mV}$.

\section{Acknowledgements}

The authors are very thankful to the Directorate General of Higher Education, Indonesia. This work was mainly funded by Hibah Unggulan Perguruan Tinggi the Directorate General of Higher Education, Indonesia, grant year of 2014 .

\section{References}

1. A. Bahtiar, A. Aprilia, Fitrillawati, Sel surya Polimer : state of Art dan Progres Penelitiannya di Universitas Pajajaran, Jurnal Material dan Energi Indonesia, 2011, Vol.01. No.01, p7 - 14

2. S. Hugger, R.Thomann, T. Heinzel, T.Thurn-Albrecht, Semicrystalline Morphology in Thin Films of Poly(3hexylthiophene), Colloid PolymSci, (2004), pp 932-938 
3. Jan Obrzut and Kirt A. Page, Electrical conductivity and relaxation in poly(3-hexylthiophene), Phys. Rev. B 80, 195211, 2009

4. A. Supriyanto, Kusminarto, K. Triyana, Roto, M.M. Salleh dan A.A.Umar.. Photosensitizing Effect of Porphyrin Films as Organic Photodetector. Journal of Materials Science and Engineering. 2010, Volume 4, No.8 (Serial No.33), p40-44

5. K. Shimatani, H. Tajima, T. Komino, S. Ikeda, M. Matsuda, Y. Ando, and H. Akiyama, The Electroluminescence Spectrum of Chlorophyll $a$, J.Chemistry Letters (2005),Vol.34, No.7 page(s) 948949

6. K. Aoki, Y. Takeuchi, Y.Amao, Visible-Light Sensitisation Nanocrystalline $\mathrm{TiO}_{2}$ by $\mathrm{Mg}$ Chlorophyll-a through Axial Imidazole 4 acetic Acid Ligand, J.Chem.Soc.Jpn., 2005, 78, pp. 132-134

7. Tang,C.W. and Albrecht,A.C., Photovoltaic effects of metal-chlorophyl-a-metal sandwich cells. J.Chem Phys 62 (1975), (6): page(s) 2139-2149

8. Sumaryanti, Utari, A. Supriyanto, B. Purnama. Karakterisasi Optik dan Listrik Larutan Klorofil Spirulina Sp sebagai Dye Sensitized Solar Cell. Jurnal Material danEnergi Indonesia. 2011. Vol 01 no 01. pp 141-147

9. A. Yakimov, High Photovoltage Multiple-heterojunction Organic Solar Cell Incorporating Interfacial Metalic Structure, Appl. PhysLett, (2002),80:1667-1669

10. A. Supriyanto, Kusminarto, K. Triyana, Roto. Optical and Electrical Characteristics of Chlorophyll-Porphyrins Isolated from Spinach and Spirulina Microalgae for Possible Use as Dye Sensitizer of Optoelectronic Devices. International Conference On Chemical Sciences. (2007). 